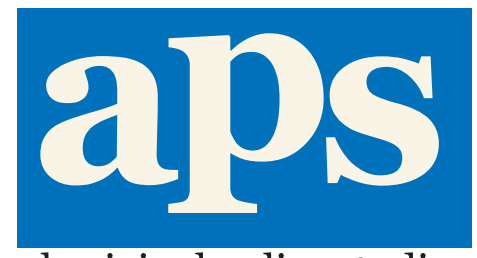

aboriginal policy studies

\title{
Article
}

\section{Commentary \\ Don't Tell Us Who We Are (Not): Reflections on Métis Identity}

\author{
Joyce Green
}

aboriginal policy studies, Vol. 1, no. 2, 2011, pp. 166-170

This article can be found at:

http://ejournals.library.ualberta.ca/index.php/aps/article/view/11687

ISSN: 1923-3299

Article DOI: 10.5663/aps.v1i2.11687

aboriginal policy studies is an online, peer-reviewed and multidisciplinary journal that publishes original, scholarly, and policy-relevant research on issues relevant to Métis, non-status Indians and urban Aboriginal people in Canada. For more information, please contact us at apsjournal@ualberta.ca or visit our website at

www.ualberta.ca/NATIVESTUDIES/aps/

or

http://ejournals.library.ualberta.ca/index.php/aps/ 


\title{
Don't Tell Us Who We Are (Not): Reflections on Métis Identity
}

\author{
Joyce Green \\ University of Regina
}

After having messed up Indian and Inuit identity for over 140 years, the federal government passed Bill C-3 in 2010 (with Royal Assent in 2011), yet another inadequate amendment to address gender inequity in the membership provisions of the Indian Act. Now, the federal government proposes to study and regulate Métis identity. This aim of regulating Métis identity was conveyed through suggestions that, among other things, federal agencies examine different Métis organizations for consistency of membership criteria.

Despite the backpedaling of some bureaucrats and politicians when the media and the Métis National Council (MNC) asked questions, it is reasonable to read this as a government wish to standardize what it means to be Métis, and to define Métis for the purposes of policies, rights claims, and other identity claims. Having unilaterally enforced a limited vision of what it means to be "Indian," arguably a category created by the colonial imagination, these sorcerers' apprentices now feel compelled to expand their expertise to the Métis.

Recognition by the state, or "status," always has been a tool of the colonial government intended to identify a discrete community for policy attention - the ultimate objective of which was assimilation - and to limit the financial liability of the colonial state. Clarifying or standardizing Métis "status" is not driven by the needs or interests of Métis communities, nor is it apparently framed by international law about self-determination and Indigenous human rights.

One danger of an authentication formula, designed for the purpose of colonial legal and administrative clarity, is that it would subject Métis, in all our diversity, to an external legitimation process. And, as history has shown, only some will be legitimated. Further, such a process indicates

aboriginal policy studies, Vol. 1, no. 2, 2011

ISSN: 1923-3299

www.ualberta.ca/NATIVESTUDIES/aps/ 
that colonialism has been so effective that some Aboriginal people rely on externally imposed criteria for internal recognition.

Identity via self-determination is one means to remedy the legacy of colonialism, but it is unclear which is the self-determining entity or entities. While the best known Métis community emerged in the Red River environment and suffered dislocation and dispersal through two military and political crises culminating in the state murder of Louis Riel and others, many other Métis communities also emerged, both in other locations and as a result of dispersal.

The Métis National Council definition of Métis privileges descendants of the historical Red River Métis; it ties identity to recognition by the Métis Nation, which eliminates many other communities and families, such as those in Newfoundland and Labrador, and in the Yukon. The MNC criteria for recognition can be, at times, problematic. For example, the criteria require applying for a Métis card from where one resides, not from where one is "from." Based on this requirement, I would have to get a benediction from the Saskatchewan Métis bureaucracy for my Métis identity, despite coming from a British Columbia family with ties to the Red River community (and with ties to the Ktunaxa Nation in southeastern British Columbia). And I would have to do so despite the fact that some of my family members have obtained Métis status by applying from our home community in BC.

A status card confers recognition of identity. As Sharon McIvor argues in her eponymous cases litigating Indian identity, it leads to feelings of selfworth. McIvor's cases challenged the sexist and racist consequences of the 1985 amendments to the status provisions of the Indian Act. Dissatisfied with the latest decision, she is now taking her case to the United Nations Human Rights Commission, arguing that Canada continues to privilege those who trace their Indian ancestry through male lines, discriminating against those who trace their ancestry through female forebearers.

In her brilliant case comment "McIvor: Justice Delayed - Again," on the challenges to the membership provisions of the Indian Act, Mary Eberts wrote:

What Canada sees as a bedeviling lack of consensus among First Nations and the National Aboriginal organizations is actually a healthy diversity, a welcome escape from the one-size-must-fit-all confines of the Indian Act. For its part, Canada should forget the exploratory process, and explore instead the simple option of simply deferring to First Nations on the citizenship issue (2011). 
And who are the Métis? Ask six different organizations or six different kinds of Métis; get an equivalent number of different definitions. As Jean Teillet (2009: 3) writes, "Métis identity is confusing to everyone." Some communities and people consider themselves "half-breed" or "breed." Others claim to be Métis by tracing ancestry to the historic Red River community. Others still claim to be 'metis,' including those who originate elsewhere on Turtle Island, such as Newfoundland and Labrador. Some are nationalist, and privilege certain originary myths. Some communities and identities are culturally formulated. Some frame boundaries between insiders and outsiders, but it is not yet clear why those boundaries are necessary, or if they are in compliance with communities' experiences (rather than political organizations' aspirations) and with international and domestic protection of Indigenous peoples.

For some Métis communities, the shared boundaries were those imposed by external racism and exclusion, and by rejection, and the result led to the creation of particular conceptions of identity and of community. This is very different than the Red River experience. Some communities became Métis by default - -- boundary people, who were not permitted to be status Indian and were rejected as white. As University of British Columbia sociologist Renisa Mawani (2009) argues, people with "mixed" heritages were stigmatized as biologically and culturally degenerate and deviant; the state sought to regulate authenticity and purity.

The colonial objective of assimilation motivated the official policy set toward Métis; the political culture of racism shaped its distinctions. Métis non-Aboriginal heritage was considered to be a step toward assimilation - a dilution of the "Aboriginal blood," understood in racist and eugenic terms. This approach viewed Métis as "less authentic" Aboriginals because of the assumption of diluted Aboriginality, thus framing colonial denial of Métis as Aboriginal through to the 1982 constitutional recognition.

As Jean Teillet suggests in her "Métis Law Summary 2009," Métis invisibility

...is the result of several factors: (1) the fact that, historically there were only two identity options in Canada -- white or Indian -because no one wanted to recognize the existence of a mixed-race people; (2) the erasure of historic aboriginal geographic boundaries; (3) the hidden language of the Métis; (4) the fact that the Métis are not phenotypically distinct; (5) a general disinclination to publicly 
identify following the events of 1870 and 1885; and finally (7) their mobility (2009:3).

Canadian colonization, sexism, and racism has damaged all Métis communities, though not all in the same way. Yet, the Métis are not walking away from recognition and the possibility of revitalization. While a lack of legislative attention and of land has contributed to cultural erosion, Emma LaRocque has rightly argued that, "cultural erosion does not mean cultural amnesia" (2001:391).

Amen: this approach is the only respectful one, consistent with international guarantees of the right to self-determination within the framework of human rights law that protects all of the members of our communities from such violations as sex discrimination. The right to selfdefinition is part of the panoply of Indigenous human rights.

Why do Métis need to be defined - for what and by whom? As with other Aboriginal peoples, the Métis are concerned with maintaining their cultures and identities but, as Emma LaRocque has argued, this is not a claim to "racial or ethnic purity or cultural superiority" (2001:396). The colonial and racialized history of Canada has led to many Aboriginal identities, and thus, of histories and communities. Not all of us fit a formula, and not many of us fit only one formula.

As Métis, we'll figure it out, and find ways to define citizenship, identity, and community. We don't need the federal or any other government to do this for us. The very polyvalent nature of Métis-ness will impel more inclusive, less absolute frameworks for identity. The definition process may take time, as communities grapple with the consequences of the long history of state and settler societies telling us who we are not. After all, we know in our psyches, in our families, that we do not - cannot - choose 'either/or' identities and be true to all that shapes us.

Joyce Green is the editor of Making Space for Indigenous feminism, and a professor in the Department of Political Science at the University of Regina.

http://blog.fedcan.ca/2011/03/15/don\%e2\%80\%99t-tell-us-who-we-arenot-reflections-on-metis-identity/comment-page-1/\#comment-11272 is the authoritative version of this piece. The modest changes here and the inclusion of references are for the purpose of aps and were not part of the original article. 


\section{References}

Eberts, Mary. 2010. Case Comment "McIvor: Justice Delayed - Again" on McIvor v. The Registrar, Indian and Northern Affairs Canada, 2007 BCSC 827 and 2007 BCSC 1732, reversed in part by McIvor v. Canada (Registrar of Indian and Northern Affairs) 2009 BCCA 153, leave to appeal denied 11.05.2009 (SCC); Supplementary Reasons (Extension of Suspension of Declaration of Invalidity) to McIvor v. Canada (Registrar of Indian and Northern Affairs), 2009 BCCA 153 (April 1, 2010). Indigenous Law Journal 2010.

LaRocque, Emma. 2001. "The Native identity and the Metis: Otehpayimsuak Peoples" in David Taras and B. Rasporich, eds. A Passion for Identity: Canadian Studies for the 21st Century. Nelson Thomson Learning, 2001. Pp 381-400.

Mawani, Renisa. 2009. Colonial Proximities: Crossracial Encounters and Juridical Truths in British Columbia, 1871-1921. Vancouver: UBC Press.

Teillet, Jean. 2009. Metis Law Summary. 546 Euclid Avenue, Toronto, Ontario, M6G 2T2. Self published by the author. 